\title{
A robotika szerepe az SNI tanulók fejlesztésében
}

\author{
Aknai Dóra Orsolya \\ Bartos Sándor Óvoda, Általános Iskola és EGYMI, Várpalota \\ IKT MasterMinds Kutatócsoport
}

\begin{abstract}
Absztrakt
Az IKT-val kapcsolatos kutatások egyik legrelevánsabb témaköre napjainkban az oktatási robotika, amit a különféle speciális igényủ diákokkal folytatott tevékenységekben is egyre gyakrabban használnak. Ebben a tanulmányban egyik célunk az volt, hogy feltárjuk a problémamegoldás, a kompetenciafejlesztés és az IKT-eszközök (esetünkben különféle padlórobot-típusok) használatának összefüggéseit. A szakirodalom vizsgálata alapján áttekintést adunk a padlórobotok osztálytermi órákba történő bevezetéséről és azok használatának kihívásairól. A tanulmányban számos olyan módszertani és robotikai eszközt mutatunk be, melyek felhasználhatók az SNI gyermekekkel való munka során. A padlórobotokkal kapcsolatos részletes információk segítséget nyújthatnak a pedagógusoknak abban, hogy a céljaiknak megfelelő eszközt tudjanak választani.
\end{abstract}

Kulcsszavak: robotika, SNI, képességfejlesztés, problémamegoldó gondolkodás, padlórobot

\section{Bevezetés}

Hosszú idő telt el azóta, hogy Seymour Papert a 1960-as évek végén kidolgozta az oktatási célú Logo programozási nyelvet és kísérletekbe fogott Teknőc nevű robotjával iskolai tanulók körében. A legújabb technológiai fejlődés és a kutatási eredmények növelték a robotika térhódítását, így a gyermekek oktatásával kapcsolatos kérdések is különös figyelmet kaptak. Napjainkban az oktatási robotika területén végzett kutatások számos lehetőséget kínálnak az SNI gyermekek fejlesztése során folytatott újításokra, különösen a tanulási nehézségekkel küzdők és/vagy értelmi fogyatékossággal élők rehabilitációjában. Az eddigi tudományos eredmények ellenére, a pedagógusok körében továbbra is fellelhető a szkepticizmus a robotok használatával szemben az SNI diákok oktatása terén. A robotika oktatásba történő bevezetésével kapcsolatban meglehetősen kevés hazai szakirodalom áll rendelkezésre (Fehér \& Aknai, 2019, 2020). Feltétlenül említést érdemel, hogy a STEM (ScienceTechnology-Engineering-Math) oktatásnak helyet kell kapnia az SNI diákok 
tanulmányaiban is, erről egyre több példát láthatunk a külföldi szakirodalomban (Villanueva, Taylor, Therrien \& Hand, 2012; Hwang \& Taylor, 2016). A gondolkodás, a kreativitás és a képességek fejlesztése egyre nagyobb hangsúlyt kap a modern oktatásban. Ennek egyik lehetséges eszköze a számítógépes gondolkodás (Fehér \& Aknai, 2018), a robotok és a kódolás bevonása a kognitív fejlesztésbe. Ma már egyre több olyan robot eszközzel találkozhatunk, amelyeket kifejezetten oktatási célokra fejlesztettek ki. Ezek a robotok az oktatás különböző színterein jelennek meg, a különböző kompetenciák, készségek komplex fejlesztésében. Tanulmányomban olyan módszertani- és robot eszközöket mutatok be, melyek használhatók az SNI gyermekekkel való tevékenység során. Támogatva az esélyegyenlőséget, a robot eszközökkel, nekik is esélyt adunk a fejlődésre, a felzárkózásra, az egyre inkább digitalizálódó világban, egyúttal jelentős motivációs bázist biztosíthatunk számukra az új tudáselemek megszerzéséhez.

\section{Képességfejlesztés}

Magyarországon az utóbbi két évtizedben egyre több szó esik a képességfejlesztés fontosságáról, sok kutatás és kísérlet foglalkozik a témával (Csapó, 2002; Nagy, 2002). A képességfejlesztés a hatékony tanulási folyamat elengedhetetlen eleme, mely nagy kihívás és felelősség, hiszen a diákok nem egyformák, eltérő képességek és szociokulturális környezet jellemzi őket. Kognitív képességeik fejlettsége meghatározza és befolyásolja a tanulók ismeretszerzését, a tananyagfeldolgozás hatékonyságát, az összefüggések felismerését, és a problémamegoldás folyamatát.

A képességfejlesztés sikerességének feltétele, hogy tudjuk az egyes gyermekeknél melyek a fejlesztendő képességek, ehhez pedig arra van szükség, hogy megismerjük a gyermeket. Ez azért is fontos, mert egy-egy gyermeknél a teljes személyiségprofil többféle képességből tevődik össze. A legáltalánosabb funkciók szerint a kognitív (értelmi), szociális, személyes és speciális képességek azok, melyeket a sikeres fejlesztés érdekében fel kell térképeznünk (Nagy, 2003). A különböző képességek fejlődése hosszú folyamat, még a legegyszerűbbek is évek alatt alakulnak ki (például a számolási készség), sok éven keresztül tartó fejlődés jellemzi őket. Ez azt jelenti, hogy a hagyományos, tantervben elöírt követelmények nem felelnek meg a képességek kialakulásának és fejlődésének kifejlesztésére. A képességfejlesztés sikeressége függ még a megfelelő motivációtól, a megfelelő tanulási környezet kialakításától és biztosításától, a szemléltető eszközök változatosságától, a tevékenységközpontú módszerek alkalmazásától és a feladatok játékosságától. Ezekre a szempontokra kiemelt figyelmet kell fordítanunk a SNI diákok képességfejlesztésében. 


\section{Az SNI tanulók definíciója, bemutatásuk}

A köznevelés területén Magyarországon a fogyatékos szó használatát az utóbbi években felváltotta a sajátos nevelési igényü (SNI) gyermek, tanuló fogalmának használata, amelyet először a többször módosított 1993. évi LXXIX. törvénnyel vezettek be. A 2011. évi CXC. törvény a nemzeti köznevelésről a fogyatékos gyermek, tanuló fogalmán a sajátos nevelési igényü gyermeket érti. Ebben az értelemben a fogyatékosság szó valamilyen tulajdonság kedvezőtlen módosulására, hiányára utal.

Sajátos nevelési igényü gyermek, tanuló (SNI) „az a különleges bánásmódot igénylő gyermek, tanuló, aki a szakértői bizottság szakértői véleménye alapján

- mozgásszervi,

- érzékszervi (látási, hallási),

- értelmi vagy beszédfogyatékos,

- több fogyatékosság együttes előfordulása esetén halmozottan fogyatékos,

- autizmusspektrum-zavarral vagy egyéb pszichés fejlődési zavarral (súlyos tanulási, figyelem- vagy magatartásszabályozási zavarral) küzd."

A sajátos nevelési igényű gyerekek valamiben különböznek ép társaiktól, ezért kiemelt figyelmet igényelnek. Oktatásuk, fejlesztésük, nevelésük a szakértői bizottság véleménye alapján, gyógypedagógiai, konduktív pedagógiai nevelési-oktatási intézményben vagy a többi gyermekkel, tanulóval együtt többségi intézményben történik (integráció, inklúzió). Az iskolai nevelés során a sajátos nevelési igény a szokásostól eltérő, nagyobb mértékű differenciálást, speciális eljárások alkalmazását, illetve a szakértői vélemény alapján kiegészítő, fejlesztő, korrekciós, habilitációs, rehabilitációs, valamint terápiás célú pedagógiai eljárásokat tesz szükségessé.

A fogyatékos személyek (ahová kategória szerint tartoznak az SNI gyermekek is) jogairól és esélyegyenlőségük biztosításáról szóló 1998. évi XXVI. törvény rendelkezik a fogyatékos személyt megillető jogokról, melynek kapcsán szót kell ejtenünk az akadálymentességről. Az akadálymentesítés nem egyenlő a rámpa használatával, hiszen ebben minden fogyatékos személy érintett (mozgássérült, látássérült, hallássérült, értelmi sérült, pszicho-szociális fogyatékossággal élő ember). Az akadálymentesség értelmezhető fizikai, infokommunikációs és komplex módon, azaz fizikai és infokommunikációs szempontból, mely biztosítja az egyenlő esélyủ hozzáférést. Jelen tanulmány esetében csak az infokommunikációs akadálymentesítéssel, annak is csak kis szeletével foglalkozunk, a számunkra érdekes területet, a robotika SNI gyermekek fejlesztésbeli alkalmazását tekintjük át.

\section{Problémamegoldó gondolkodás}

Molnár (2016) tanulmányában, mely a 9-19 éves korosztály dinamikus problémamegoldó képességére irányul, arra a következtetésre jut, hogy a di-

${ }^{1}$ 2011. évi CXC. Törvény 4.\$ 25. 
ákok induktív gondolkodásának fejlettségi szintje jelentős prediktív erővel bír problémamegoldó gondolkodásuk fejlettségi szintjére, egyben felhívja a figyelmet az iskolai sikeresség és a tudás alkalmazhatósága, a problémamegoldó gondolkodás fejlettségi szintje közötti szakadékra (Molnár, 2016, p. 14). Ennek fényében érthető, hogy a problémamegoldó gondolkodást a kulcsfontosságú képességek közé sorolták (Molnár, 2012), melynek fejlesztése ma már sok ország oktatási programjának alapvető részét képezi (OECD, 2010).

A problémamegoldó gondolkodás edukációjában gyakorlati terepet nyújt a robotokkal való foglalkozás. A legmagasabb szintü kognitív funkció a gondolkodás és gyakran tapasztaljuk, hogy az SNI gyerekeknél, különösen az értelmi sérült gyermekeknél ez a folyamat sérül. A gondolkodás teszi lehetővé az ember számára a beszéd elsajátítását, a fogalmak elsajátítását, a szabályok megfogalmazását, a problémák megoldását és a következtetések levonását. A problémamegoldó gondolkodás során szembe találkozunk egy problémával melynek megoldásához meg kell találnunk az utat. A robotokkal való tevékenységnek ugyanúgy négy, egymástól jól elkülönülő szakasza van, mint a problémamegoldó gondolkodásnak (Pólya, 1969). Ezek a következők:

\section{A probléma megértése}

Az első a probléma, a feladat megértése, melyen belül hívjuk fel a gyermek figyelmét arra, hogy mit kell keresnie, mik a meglévő adatok, milyen kikötéseket teszünk. A kikötések kielégítőek-e a probléma megoldásához, van-e benne ellentmondás, vagy esetleg kevesebb kikötés is elegendő a megoldáshoz? A jobb megértés érdekében érdemes ezeket a kikötéseket részekre bontani, rajzolni, jelöléseket használni.

2. Tervkészítés

A második lépés a tervkészítés, ahol a gyerekek figyelmét fel kell hívni, hogy gondolkodjanak el azon, nem találkoztak-e már valahol hasonló problémával, van-e olyan ismeretük máshonnan, amelynek hasznát vehetik a megoldás során. A gyerekeknek nyújtsunk segítséget, ha nem értik a feladatot, fogalmaztassuk át velük, illetve kérdezzük meg, hogy minden adatot felhasználtak-e a terv elkészítéséhez, végül készíttessünk velük megoldási tervet. Ezt minden esetben papíron érdemes lejegyezni.

3. Kivitelezés

Hívjuk fel a gyermek figyelmét, hogy kísérje figyelemmel a megoldást, hiszen ha hibás, ennek függvényében lesz képes korrigálni azt. Tegyünk fel kérdéseket: Biztos vagy abban, hogy a lépések helyesek? El is tudod mondani, hogy miért?

4. Vizsgálat

Kérdezzük meg, hogy tud-e más megoldást a feladat (probléma) megoldására? Mi lehettet a hiba, ha nem lett jó a megoldása?

A következőkben a téma szempontjából legérdekesebb területet tekintjük át. 


\section{Robotika szerepe az SNI gyermekek oktatásában}

A „robotika” kifejezés számos kutatási területet foglal magába. Az egyik ilyen terület a social robotics (szociális), melyek olyan robotok, amelyek beszéd, gesztusok vagy más kommunikációs eszközök révén valamilyen formában szociális interakcióba lépnek az emberekkel (Fong, Nourbakhsh \& Dautenhahn, 2003). A robotika egy másik területe az assistive robotics (segítő), ahol általában olyan robotokat alkalmaznak, amelyek segítenek a fogyatékossággal élő embereknek, elsősorban a testi és idegrendszeri fogyatékossággal szemben (Miller, 1998). A Socially assistive robotics (SAR) (szociális segítő robotok) egy gyorsan kialakulóban lévő terület, amely e kettő metszéspontjában fejlődik ki, és olyan robotokkal foglalkozik, amelyeket úgy terveztek, hogy multimodális interfészek (beszéd) útján segítsék elő a felhasználói igények által vezérelt, fejlett interakciót. Használható az oktatás, a fizikoterápia, a napi élet segítése, az érzelmek kifejezése során (Feil-Seifer \& Mataric, 2005).

Manapság az oktatási robotikát az oktatás különböző dimenzióiban vezetik be, így például a speciális igényü gyermekek oktatásába. A robotika iskolákban való felhasználásáról szóló tudományos irodalmat Benitti (2012) tekintette át és javasolta, hogy az oktatási robotika olyan elemként működjön közre, amely elősegíti a tanulást, ha azt megfelelő módon alkalmazzák. Különösen a robotasszisztensek képesek legyőzni az aggodalmakat, mivel ösztönzik a gyermekeket a részvételre. A mozgássérült gyermekek akkor vesznek részt inkább a motoros feladatokban, amikor robotokkal léphetnek kapcsolatba. A robot gyakorlati tanulási partner lehet, mely motiválja a diákokat a cselekvésbe ágyazott tanulásra. Tehát az oktatási robotika eszközként szolgálhat a tudás felépítéséhez és segítő eszközként azoknak a diákoknak, akiknek problémái vannak bizonyos területeken. Az oktatási robotika nem tekinthető csodaszernek az SNI gyermekek oktatásában felmerülő öszszes probléma megoldására, ugyanakkor az inkluzív oktatás fontos alapelve az, hogy „gyermeket nem hagyunk hátra”.

Ezen kívül nem elfogadható, ha a pedagógusok olyan tevékenységeket, fejlesztő foglalkozásokat iktatnak be, amelyek feltételezhetően inkluzívak, de az egyéb hatásokat nem veszik figyelembe. Például, ha a pedagógus úgy dönt, hogy az agyi bénulásban szenvedő diákkal robot asszisztált tevékenységet szervez, nem elfogadható a fejlesztés, ha nem vesszük figyelembe, hogy ezek a tevékenységek sok stresszt okozhatnak az azt használó diáknak (kérdés, képese a gyermek apró részletekkel operálni?). Vagy ha a pedagógus úgy határoz, hogy csoportos tevékenységeket szervez autista spektrumzavarral rendelkező gyermekek számára, akkor nem elfogadható, ha nem vesszük figyelembe, hogy ezeknek a gyerekeknek a csoportos tevékenységekben való részvétel rendkívüli stresszt okozhat, és hogy ezek a tevékenységek stresszhelyzetben tarthatják az autista gyermekeket, ami blokkolja a tanulás lehetőségét (Scassellati et al., 2012). Ezek a példák annak szemléltetésére szolgálnak, hogy az oktatási robotikát többdimenziós módon kell elemezni, figyelembe véve nemcsak a közis- 
mert problémákat, hanem az összes rejtett szempontot is. Egyébként a befogadás csak hamis befogadás lehet, és nem támogathatja a tudásépítést, a tanulási motiváció megváltoztatását és a diákok jóllétét.

Hogyan tudja segíteni a mesterséges intelligencia az oktatást? Milyen szerepet tölthet be egy robot a tanórán? Segíti vagy megnehezíti a tanár oktató-nevelő tevékenységét? Sok kérdést fogalmazhatunk meg ebben a témában, főleg akkor, ha SNI gyermekekkel foglalkozunk. Gyakorló gyógypedagógusi munkám során rendszeresen alkalmazok különféle padlórobotokat és kódoláshoz, alapszintủ programozáshoz használható eszközöket az SNI gyermekek oktatásában. Ezek elsősorban olyan eszközök, melyek egyszerű működési elven alapulnak, fejlesztik az algoritmikus gondolkodást és a logikai gondolkodást. A tanítványaink számára nem ismeretlen a digitális világ, ezért a roboteszközök használata óriási motivációs bázis, az újdonság varázsa felkelti és fenntartja a diákok érdeklődését.

Az SNI gyermekek fejlesztésében elsődleges szempont a játékos tanítás, fejlesztés. Amikor egy roboteszközt bemutatunk a gyerekeknek, egy olyan belső motivációs bázist tudunk aktiválni, amely hagyományos eszközökkel csak nehezen mozgósítható. Bármilyen sérüléssel rendelkező gyermeket könnyedén motiválhatunk egy kedves, esetleg beszélő padlórobottal. A robotok segítségével a különböző feladatokon keresztül a gyerekek játszva tanulják meg a robotika és a kódolás alapjait. A robotokkal tevékenykedve aktívan, cselekvésbe ágyazottan sajátítják el a különböző tantárgyi tartalmakat, illetve a robotokkal végzett fejlesztő feladatok által fejlődnek a különböző készségeik.

SNI gyermekek fejlesztésének egyik kiemelt célja a sikeres kommunikáció megalapozása, az ahhoz szükséges képességek kialakítása és fejlesztése. A nyelvi és kommunikációs képességek megléte és minősége a gyermek iskolai, később társadalmi érvényesülését meghatározó módon befolyásolják. A megfelelő működés megerősíti a nyelvi jelrendszer megértését, kódolását, értelmezését, tárolását és alkalmazását, illetve a gyermek tanuláshoz való viszonyát is nagymértékben befolyásolja. A nyelvi és kommunikációs képességek feltérképezésekor, majd a terápia alkalmazásakor komplex szemlélettel kell gondolkodni. Ebbe a jól megtervezett terápiás eljárásba - a hagyományos módszerek és eszköztár mellett - vonhatóak be a padlórobotok.

A leghatásosabb tanulási forma a játékon belüli tanulás, mely idomul a gyermek szükségleteihez, vágyaihoz, ugyanakkor szabad teret nyújt a próbálgatásoknak. A nyelvi, kommunikációs játékok alkalmazásával, melybe bevonjuk a padlórobotokat is, a gyermekek játékosan, tapasztalatokba ágyazva ismerik meg anyanyelvüket. Az anyanyelvi játékok fejlesztik a beszédpercepciót, a beszédmegértést és a beszédprodukciót, valamint elősegítik az ösztönös nyelvi ismeretek rendszerezését és tudatos alkalmazását. A tevékenységek közben a gyermekek különböző kognitív folyamatokat aktivizálnak, kreatívabbá válnak, és a beszédgátlásokkal küzdők a robot segítségével oldódnak, megnyilatkoznak (Gósy, 1994). 
A 2000-es évek eleje óta számos kutatás történt azért, hogy jobban megértsék az oktatási robotok eszközként történő használatát az interakció és a kommunikáció előmozdításában, például az autizmusban. Ezek a tanulmányok foglalkoztak az oktatási robotika használatának sikerességével, a szociális és kommunikatív viselkedés javítása érdekében, az autizmusspektrum-zavarral rendelkező gyermekek és serdülők körében (Scassellati, 2005; Palestra \& Bortone, 2016; Palestra et al., 2017). Az autizmus robotterápiáját az elsők között fedezték fel a szociális segítő robotok kontextusában (SAR), melynek célja olyan robotok kifejlesztése volt, melyek segítenek az embereknek a speciális szükségletek szociális interakciókon keresztüli kifejezésében (Scassellati, 2005).

Ebből is látható, hogy a robotok lehetőséget teremtenek nem csak egy nem fenyegető, háromdimenziós élettelen tárgyról történő tanulásra, hanem más emberekkel való interakción keresztül történő tanulásra is, ezáltal is ösztönözve az autonóm társadalmi magatartást. Ez lehetővé teszi a robotok számára, hogy segítsenek különféle emberi jellegű funkciók ellátásában, valamint segítséget nyújtsanak a fogyatékossággal élő személyek társadalmi készségeinek fejlesztésében is (Houwen et al., 2014).

Ribu (2010) tanulmányában azt feltételezi, hogy az autista diákokat különösen vonzza a számítógép-tudomány, hiszen a számítógépek logikusak és következetesek, nem úgy, mint a szociális kölcsönhatások, melyeket gyakran nehéz kezelni. Autista diákjai az olyan típusú problémákat részesítik előnyben, melyben nagy mennyiségű adat kezelésére válnak képessé. Szerinte a megbízható struktúrák felépítése hasznos és kiszámíthatóvá teszi az eredményeket.

A differenciálást igénylő vagy fejlesztő foglalkozásokon sok olyan hagyományos és új, modern IKT-eszközt vehetünk igénybe, melyek az SNI gyerekek képességeinek fejlesztését hatékonyabbá teszik. Ilyen eszközök az általunk is használt robotok, padlórobotok. Mivel ezek az eszközök közvetlen kapcsolaton alapulnak, a tanulók azonnali visszajelzést kapnak a tevékenységükről, valamint annak eredményéről. A robotok játékosan nyújtanak segítséget a gyermekek figyelmének, emlékezetének, gondolkodási funkcióinak fejlesztésében. Az érzelmeken alapuló gyermek-robot interakció elősegíti a figyelemkoncentrációt, javítja az információk érzékelését a tanulás és a verbalizálás során. Ez az a folyamat, mely jó hatással van a gyerekek pedagógiai rehabilitációjára, valamint fejleszti érzelmi kultúrájukat is a robotokkal való tevékenykedés során. Az érzelmeknek jelentős szerepük van a gyerekek kognitív folyamatainak befolyásolásában, így az észlelés, figyelem, tanulás, memorizálás, problémamegoldás gyorsan és automatikusan koncentrálja a gyerekek figyelmét és megkönnyíti az észlelési folyamataikat.

A robotok az SNI gyermekekkel való foglalkozásban biztonságos és semleges tanulási környezetet biztosítanak. Egy robot soha nem fog megítélni valakit vagy kinevetni a hibákért. Ez különösen azoknak a gyerekeknek hasznos, akik introvertáltak vagy nem tanulnak olyan gyorsan, mint mások, 
lehetővé téve számukra, hogy szégyen, vagy társaik nyomása nélkül összpontosítsanak a tanulásra. A robotok nem fáradnak el az ismétlődő feladatok végrehajtása közben. Soha nem vesztik el a türelmüket, így a gyermekek számára lehetővé teszik, hogy a saját tempójukban haladhassanak a tanulásban. Az SNI gyermekeknek általában hosszabb idő elsajátítani valami újat, de a robotok segítségével annyiszor próbálkozhatnak, ahányszor szeretnének, és a robotok soha nem fogják azt érezni, hogy a tanulási, elsajátítási folyamat túl sokáig tart. Ösztönzik a gyerekeket a tanulásban való aktív részvételre. Ez a motiváció szempontjából elengedhetetlen, hiszen a gyermekeknek megfelelő a motiváltsága és az elköteleződése, így sokkal gyorsabban érhetik el tanulási céljaikat. Visszajelzést adnak a pedagógusoknak. Ha jó megfigyelők vagyunk, és a gyermek-robot interakcióról folyamatosan feljegyzéséket készítünk, láthatjuk, hogy melyik az a terület, ahol a robotok elősegíthetik a munkánk hatékonyabb elvégzését.

\section{Padlórobotok használatának előkészítése, bevezetés a fejlesztésbe}

A robotok hihetetlenül értékes tanítóeszközök lehetnek, de a lehető legjobb eredmény elérése érdekében fontos, hogy ezeket megfelelően valósítsuk meg. Javasoljuk, hogy a robotok osztálytermi használatának tervezésekor kövessük a következő négy alapelvet:

\section{Legyen világos célja a használatnak:}

Határozzuk meg azt a konkrét tanulási célt, amelyet a robot segít elérni, és csak akkor használjuk a robotot, ha általa el tudjuk érni a kívánt célt.

2. Használjuk a robotokat az ismétlödö feladatok elvégzésére:

A különböző roboteszközök nagyon jól képesek végrehajtani az ismétlődő feladatokat, amelyek gyakran unalmasak és időigényesek lehetnek a gyerekek számára, így megismerhetik az algoritmusok müködési elvét is a tanítványaink.

3. Ügyeljünk arra, hogy a tanítványaink ne kötödjenek túlzottan a robothoz: Mivel a gyerekeknek nagyon sok emberi társadalmi interakcióra van szükségük, fontos, hogy megbizonyosodjunk arról, a gyerekek megértik, hogy a robot ott van ugyan, hogy segítsen nekik a tanulásban, de nem mint barát vagy szociális lény vesz részt az életükben.

4. Kövessük az etikai irányelveket:

Amikor a robotokat az osztályteremben használjuk, elengedhetetlen a megfelelő etikai irányelvek betartása. Ahogy a technológia térnyerése minden nap erősebbé válik, az etika szerepe is egyre fontosabb része az életünknek, és ez vonatkozik a robotok használatára is.

Gyakorlati tapasztalat alapján elmondható, hogy a robotok használatát minden esetben elö kell készíteni a könnyebb megértés érdekében. Mivel SNI gyermekekről van szó, ajánlatos a robot mozgását először a saját testen megtapasztaltatni a gyermekkel. Következő lépés, amikor már párban dol- 
goztatjuk a gyerekeket, ahol az egyik diákunk a „távirányító”, a másik gyermek pedig a robot. Ezt először gyakoroltassuk a gyerekkel úgy, hogy nincs akadály, majd nehezíthetjük a feladatmegoldást egy, illetve több akadály beiktatásával (Aknai \& Fehér, 2019).

Ahhoz, hogy a diákjainknak ez ne okozzon problémát, jól kell tájékozódniuk térben. A térbeli tájékozódás tulajdonképpen az egymás mellé kapcsolódó, háromdimenziós és kétdimenziós eligazodás. Az a gyermek, aki a háromdimenziós térben már jól tájékozódik, nem biztos, hogy síkban is jól el fog igazodni. Az átvitel nem biztos, hogy létrejön, a háromdimenziós térben már jól eligazodó tanítványunkat elképzelhető, hogy át kell vezetnünk majd a kétdimenziós felületre. Ezért is nagyon fontos, hogy a gyerek a saját testhatáraival, testrészeivel, a jobb és a bal, valamint az alatt, fölött, között, mögött, mellett, előtt viszonyfogalmakkal tisztában legyen. Ezeket ismerniük kell a saját testükön, a térben elhelyezett tárgyak esetében, és síkban a feladatlapokon is.

A téri tájékozódás alapja a kialakult dominancia, illetve a szilárd testséma.: Bizonytalan laterális dominancia bizonytalan testsémát és irányészlelést okoz, az írás-olvasás-számolás elsajátításának ez a legnagyobb akadálya. A szilárd testséma azt jelenti, hogy, az idegrendszer felismeri az egyes testrészek egymáshoz való helyzetét, mozdulatokat tervez és rendez össze, felismeri az „én” és a környezet viszonyait. Ennek a képességnek a fejlődése eltér a többi koordinációs képesség fejlődésének szakaszától, mely általában 7-12 éves korig tart. SNI gyermekek esetében ez az időszak még inkább kitolódik. Ezért ezeknél a gyerekeknél a fejlesztés hangsúlyait a térbeli helyzet felismerésére, megnevezésére (fent-lent, elöl-hátul-középen), és a térbeli helyzetek megfogalmazására, azaz arelációs szókincs fejlesztésére helyezzük.

Gyakorlati tapasztalatok azt mutatják, hogy mint minden más fejlesztésben, itt is be kell tartani a fokozatosság elvét, a padlórobotokkal való tevékenységet igen komoly tervezőmunkának kell megelőznie. Meg kell határoznunk a nehézségi szinteket, ahhoz tevékenységeket és feladatokat kell rendelnünk (Aknai \& Birinyi, 2019).

1. Az első szint, amikor egyszerű algoritmust hajtatunk végre a gyermekkel, tehát két pont közötti egyszerű mozgást. A gyermek feladata végrehajtani az egyszerü kódsort: jusson el A pontból B pontba.

2. Következő szint, amikor már kész, összetettebb algoritmusokat kell végrehajtaniuk a gyerekeknek, tehát több pont között kell mozogniuk. Például, amikor ugyancsak A-ból kell eljutni B-be, de közben nem érintheti a $\mathrm{C}$ pontot.

3. A harmadik fokozat, amikor az egyes és kettes nehézségi szintű algoritmust, adott feltétel szerint kell átalakítania a gyermeknek, ezáltal meg kell változtatni az utasítás sort úgy, hogy most is A pontból kell eljutnia $B$ pontba, de közben érinteni kell a $C$ pontot. Ilyenkor a gyerekek megbeszélik, hogyan kell a megadott utasításokat módosítaniuk úgy, hogy a feltételek teljesüljenek. 
4. A negyedik szinten az egyes nehézségi szintű feladathoz a gyerekek önállóan készítenek algoritmust. Ekkor csupán a kezdő és végpontot adjuk meg, és ehhez kell megtervezniük az útvonalat. A kérdés az, hogyan juthatnak el A pontból B pontba.

5. Innen akkor lépnek tovább a gyerekek, amikor már úgy mozognak több pont között, hogy ők készítik el az útvonalakat, alkotják meg az algoritmusokat.

6. A legmagasabb szint, amikor már az egyes vagy kettes nehézségű feladathoz önállóan készítenek algoritmust a gyerekek. Ekkor többféle utat keresnek a megoldáshoz és ezeket az algoritmusokat össze is hasonlítják egymással.

1. táblázat

Robotokkal való fejlesztés nehézségi szintek szerinti besorolása (Aknai E Birinyi, 2019)

\begin{tabular}{|c|l|l|l}
\hline $\begin{array}{c}\text { Nehézségi } \\
\text { szint }\end{array}$ & \multicolumn{1}{|c|}{ Tevékenység } & \multicolumn{1}{|c}{ Feladat } & Gyermeki tevékenység \\
\hline $\mathbf{1}$ & $\begin{array}{l}\text { Kész, egyszerú algoritmusok } \\
\text { végrehajtása. Mozgás két pont } \\
\text { között. }\end{array}$ & $\begin{array}{l}\text { Hajtsák végre a megadott kódsort! } \\
\text { Jussanak el A-ból B-be! }\end{array}$ & $\begin{array}{l}\text { A gyerekek eljátszák az elöre } \\
\text { megadott utasitásokat. }\end{array}$ \\
\hline $\mathbf{2}$ & $\begin{array}{l}\text { Két, összetettebb algoritmus } \\
\text { végrehajtása. Mozgás több pont } \\
\text { között. }\end{array}$ & $\begin{array}{l}\text { Hajtsák végre a megadott kódsort! } \\
\text { Jussanak el A-ból B-be, de (ne) } \\
\text { érintsék C-t! }\end{array}$ & $\begin{array}{l}\text { A gyerekek eljátszák az elöre } \\
\text { megadott utasitásokat. }\end{array}$ \\
\hline $\mathbf{3}$ & $\begin{array}{l}\text { 1-es vagy 2-es szintú algoritmusok } \\
\text { átalakitása, adott feltétel alapján. }\end{array}$ & $\begin{array}{l}\text { Változtassuk meg az adott kódsort } \\
\text { úgy, hogy jussanak el A-ból B-be, } \\
\text { de érintsék C-t! }\end{array}$ & $\begin{array}{l}\text { Megbeszélik, kipróbálják, hogy } \\
\text { lehet a megadott utasitásokat } \\
\text { módositani, hogy teljesüljön a } \\
\text { feltétel. Új algoritmus kódolása. }\end{array}$ \\
\hline $\mathbf{4}$ & $\begin{array}{l}\text { Algoritmus létrehozása önállóan, } \\
\text { 1-es szintú feladathoz. }\end{array}$ & $\begin{array}{l}\text { Tervezzék meg, hogyan lehet eljutni } \\
\text { A-ból B-be! }\end{array}$ & $\begin{array}{l}\text { Ónállóan alkotják meg a } \\
\text { feladathoz az algoritmust. }\end{array}$ \\
\hline $\mathbf{5}$ & $\begin{array}{l}\text { Algoritmus létrehozása önáloan, } \\
\text { 2-es szintú feladathoz. }\end{array}$ & $\begin{array}{l}\text { Tervezzék meg, hogyan lehet eljutni } \\
\text { A-ból B-be úgy, hogy (ne) érintsék } \\
\text { C-t! }\end{array}$ & $\begin{array}{l}\text { Önállóan alkotják meg a } \\
\text { feladathoz az algoritmust. }\end{array}$ \\
\hline $\mathbf{6}$ & $\begin{array}{l}\text { Algoritmus létrehozása önállóan, } \\
\text { 1-es vagy 2-es szintú feladathoz. }\end{array}$ & $\begin{array}{l}\text { Keressenek többféle utat A-ból B- } \\
\text { be, esetleg közben (ne) érintsék C-t! }\end{array}$ & $\begin{array}{l}\text { Önállóan alkotnak a feladathoz } \\
\text { többféle algoritmust, azokat össze } \\
\text { is hasonlitják. }\end{array}$ \\
\hline
\end{tabular}

Amikor tanítványaink ezeket a tevékenységeket jól elsajátították úgy, hogy robotot még nem használtak, tehát saját testükön tapasztalhatták meg a téri irányokat, az algoritmusok felfedezését, a feladatok nehézségét, bevezethetjük a robotok használatát.

\section{Hogyan válasszunk robotot?}

Az első és nagyon fontos szempont, hogy kikkel, milyen korú és sérülésü gyerekekkel foglalkozunk, az ő képességeikhez hogyan illeszthető be a robotokkal való tevékenykedés. Ez azért is fontos, mert magában a robot még nem elég a fejlesztő munkához. Másfajta roboteszköz használható az értelmi 
sérült, a mozgássérült gyerekeknél, mint a beszédfogyatékos, de ép értelmű tanítványainknál. A robotok általában pályán mozognak, némelyikhez különböző tartozékok is társulhatnak. Egy mozgásában korlátozott, ép értelmü gyermeknek, aki esetleg kerekes székben ül, másképpen kell pozícionálnunk a robotot és a robotpályát, mint egy értelmi sérült, vagy siket tanuló esetében. Érdemes kikérnünk olyan kollégák véleményét, akik már régóta foglalkoznak oktatási robotok használatával az SNI diákok körében.

Ma már hazánkban is egyre bővülő kínálattal találkozhatunk az oktatási robotok terén, de játékboltokban is rábukkanhatunk olyan robotokra, melyek megfelelnek a céljainknak. Másik szempont az anyagi forrássok rendelkezésre állása a robotok beszerzését illetően, kell-e még vásárolnunk hozzá egyéb tartozékokat (pálya, irányítópanel, kártyák, szoftver), az intézmény finanszírozza a beszerzést vagy saját forrásból kívánjuk fedezni azt. A robotok árának vonatkozásában nagy a szórás, ezért érdemes kellően tájékozódni a vásárlás elött. Ahhoz, hogy jól ki tudjuk használni a padlórobotok adta lehetőséget, nagy valószínűséggel szükségünk lesz különféle pályákra (szőnyegekre), amit akár a tanítványainkkal együtt is elkészíthetünk.

A teljesség igénye nélkül megemlítünk néhány olyan robotot, mely az SNI gyermekek fejlesztésében a hazai gyakorlatban hasznosnak bizonyultak (Fehér \& Aknai, 2019, 2020).

\section{Code a Pillar}

Az óvodásoknak, kisiskolásoknak kifejlesztett „játék”, amelynek az elemeit különféle sorrendben lehet összerakni, így a hernyó minden alkalommal más-más útvonalon fog haladni. Amikor a gyerekek átrendezik az elemek sorrendjét, a hernyó más irányba fog haladni, ugyanakkor fény- és hangeffektekkel is szórakoztat. A csomagban nyolc elem van, egyikük hangot ad, három egyenesen, kettő balra, kettő pedig jobbra halad. A játék kombinációs lehetőségeinek száma elég sok (sőt, kiegészítő csomag is kapható). A hernyó feje mozog-világít, a szeme villog, kedves hangokat ad és szinte a megszólalásig hasonlít egy igazi hernyóhoz. Használatához négy darab AA elemre van szükség. A gyerekek versenypályát tudnak készíteni a start és cél korongok lehelyezésével, majd elvezethetik a célba a robotot. Eközben a gyerekek gondolkodnak, és új lehetőségeket fedeznek fel. A játék használata fejlesztheti a finommotoros készségeket, a kreativitást, arra ösztönzi a gyerekeket, hogy új dolgokat próbáljanak ki, ráadásul fejleszti a problémamegoldó gondolkodásukat is. A játék mobilapplikációban is megtalálható.

\section{Blip}

Blip, a beszélő robot anyanyelve spanyol, ezenkívül angolul és magyarul is beszél. A gyártó négyéves korú vagy idősebb gyerekeknek ajánlja, így szerintünk alsó tagozatos SNI gyermekek számára is használható eszköz. Blip küldetéseket teljesít, melyben a gyerekek segítségét kéri. A küldetések a ro- 
bothoz mellékelt füzetben találhatók, szintén három nyelven. A küldetések nagyon egyszerüek, a robot használatának megtanulásában segítenek: a robot mozgásainak beprogramozását tanítják meg a gyerekeknek, miközben a küldetések mellé szöveges tudnivalókat is közölnek. Összesen 20 küldetést tartalmaz a füzet, amelyek az egy lépésestől az öt lépéses feladatokig terjednek. A robothoz egy puzzledarabokból összerakható pálya is tartozik, amely nyolc elemből áll. A füzetben lévő küldetések az ezekből összerakott pályákon valósíthatók meg. A robot programozása a tartozékként adott távirányítóval történik, mely meglehetősen egyszerü, összesen öt gomb található rajta: elöre, jobbra, hátra, balra, valamint a „küldetés” gomb. Lehetőség van a "szabad küldetés” módban használni Blipet, tehát programozható. A leírásban nincs információ, hány lépést tud végrehajtani, használat alapján azt tudjuk mondani, hogy 25 lépéssel sikeresen megbirkózik.

\section{Bee-Bot, Blue-Bot}

Mindkettő eszköz a méhecskéket modellezi, melyek a hátukon lévő iránygombok segítségével programozhatóak. Könnyen a gyerekek kedvencévé válnak, hiszen amellett, hogy programozni lehet őket és végrehajtják a parancsokat, villognak és hangot is adnak. A méhecskék 15 x 15 cm-es lépésekben tudnak közlekedni. Tökéletes eszköz a térbeli, síkbeli viszonyok tanításához, gyakorlásához, illetve a programozási alapismeretek játékos, cselekvésbe ágyazott elsajátításához. A Bee-Bot memóriája 40 lépésig, a Blue-Boté pedig 200 lépésig programozható. A Blue-Bot okoseszközről (a letölthető applikációnak köszönhetően) vagy PC-ről (szoftver segítségével) is vezérelhető. A Blue-Bot a Bee-Bottal ellentétben okoseszközről vezérelve 45 fok-ban is el tud fordulni. Az eszközökön elkészített kódot közvetlen Bluetooth-kapcsolaton keresztül lehet elküldeni a robotméhecskének. Természetesen, csak Bee-Bot üzemmódban is használható.

\section{EaRL}

A robotot a Hope Education szakemberei és oktatói fejlesztették ki a legkisebbeknek, illetve a sérült gyermekeknek, hogy a pedagógusok és tanítványaik vele sajátítsák el az alapvető kódolási ismereteket. Használatát a szakemberek már hároméves kortól ajánlják! Programozható padlórobot színes fényekkel és különböző hangokkal, melyek multiszenzoros élményt nyújtanak a gyerekeknek, ugyanakkor bevezetik őket a számítógépes gondolkodás és a programozás alapjaiba. A gyermekek hangfelvételt készíthetnek a saját hangjukról, és azt a robotra egy USB-kábel segítségével átvihetik, hogy az lejátssza. Az EaRL-höz tartozik egy tanári útmutató, és több tananyag leírás is (a gyártó weboldaláról angol nyelven letölthetők, online olvashatók), melyek jó vezérfonalat adnak a programozás elsajátításához. A gyerekek feladatkártyák használatával a programozás előtt meg tudják tervezni a megteendő lépéseket. A robot távirányítással is mozgatható, ha a kész programsort - ame- 
lyet a számítógépen írtak meg a gyerekek - USB-kábellel rátöltik a robotra, ugyanis a robot kompatibilis a Scratch-csel. Ez azt jelenti, hogy a tanulási, haladási folyamat egyszerü, ingyenes és valós kódolási környezetet biztosít az ügyes „programozók” számára. A robot 250 lépéses programmemóriával rendelkezik.

\section{Ozobotok}

Kézben, tenyérbe elférő zsebrobotok. Kétféle változat van belőlük, az Ozobot Evo és Ozobot Bit. A kódolás tanítására-tanulására és a kreativitás kibontakoztatására fejlesztették ki. Kétféle módon kódolhatók: online az OzoBlockly-val és „képernyő-mentesen”, színes kódokkal. A színes kódok mondják meg az Ozobotoknak, hogy mit kell tenniük. A színes kódok olyan alapvető kódolási elveket tanítanak, mint az ok-okozat, a kritikus gondolkodás és a hibakeresés. A robotok érzékelőkkel követik a vonalakat és elolvassák a jelölőkkel (vagy matricákkal) készített színkódokat. A „színes” programozáshoz színkódtábla van a segítségünkre.

\section{Edison}

Kétféle felületen programozható (blokkfelületen [EdBlock] és karakteres alapú [EdPy] programozási nyelven), képes infraalapú kommunikációra, beépített szenzorokkal is rendelkezik, és az alaprobot további kiegészítőkkel bővíthető. A tapsvezérelt mozgás, a vonalkövetés, fénykövetés és a távirányítás csak pár dolog a jó tulajdonságai közül. Lego-kompatibilis, így csak a gyerekek fantáziáján és kreativitásán múlik, hogy minek „öltöztetik fel”. Ez a tulajdonsága a történetmesélés, a digitális történetmesélés során is használhatónak ígérkezik.

Alkalmazása előtt szükséges a pedagógusok felkészítése az adott eszköz használatára, ami online vagy blended learning továbbképzési formában is megvalósítható, mivel a robot használatának/programozásának megtanulása a padlórobotok használatánál jóval összetettebb ismereteket igényel.

\section{Kihívások a robotok alkalmazásában}

Az oktatás, a digitális pedagógia és a robotika változása, ezek fejlődése a gyógypedagógiai gyakorlatot is folyamatosan befolyásolják. Ilyen befolyásoló tényezők lehetnek az integráció (beolvasztás, összevonás), az inklúzió (befogadás) megvalósulásának mértéke, a megváltozott tanulási környezet, a gyermekek szociális háttere, valamint az oktatással, intézményekkel szemben a társadalom által támasztott változó igények. Ebből kifolyólag a pedagógusok és tanítványaik folyamatos kihívások elé vannak állítva. Ha IKT-eszközökkel segített oktatással, -fejlesztéssel akarjuk a ránk bízott diákokat fejleszteni, első és legszembetűnőbb akadály lehet, ha nem áll elegendő és megfelelő eszköz a rendelkezésünkre. A robotok esetében csak ritkán alkalmazható a BYOD-mód- 
szer („Hozd a saját eszközödet”), hiszen jelenleg nagyon kevés olyan gyermek van a tanítványaink között, akik otthon is rendelkeznek roboteszközökkel, de ezek száma lassan növekszik. Ilyenkor kérhetjük a családokat, hogy a gyerekek hozzák be az órára az eszközüket, mutassák be a többieknek, ismerkedjünk meg közösen a használatukkal. Ha nincs valódi robotunk, az is kérdés lehet, hogy léteznek-e alkalmas, helyettesítő szoftverek a tantervi célok megvalósítására? Néhány padlórobot esetében léteznek weboldalak (Bee-Bot Emulator), illetve applikációk, melyek helyettesíteni próbálják a roboteszközöket, de ezek éppen az egyik leglényegesebb tényezőt, a fizikai interakciót kapcsolják ki a folyamatból. Abban az esetben, ha robot helyett használjuk ezeket az eszközöket, vagy okos eszközzel együtt használjuk a robotot, felléphetnek zavaró tényezők is, hiszen az eszköz el is terelheti a figyelmét a gyermeknek. A robotok használatához ajánlott a gyerekekkel együtt megalkotni egy eszközhasználati „kódexet”, mert ha a tanítványainkat a szakszerü eszközhasználatra neveljük, kiküszöbölhetjük az eszközök rongálódását. Ha robotokat, programozható eszközöket többen is használunk egy intézményen belül, előfordulhat, hogy a tervezésünk ellenére nem áll majd rendelkezésünkre az eszköz. Ezért kívánatos táblázatban vezetni, előre egyeztetni a kollégákkal az eszközhasználatot, valamint szabályokban megegyezni például a használatot, töltést, visszahelyezést illetően. Kihívásként jelenik meg, ha lehetőségek híján a pedagógusnak magának kell beszereznie ezeket az eszközöket. Kérdésként merül fel, hogy meddig terhelhető a pedagógus pénztárcája?

\section{Összegzés és jövőkép}

Jelen tanulmányomban áttekintettem a robotika eszközeinek és lehetőségeinek felhasználását az SNI tanulók oktatásában. Mivel a mesterséges intelligencia (AI) és a robottechnológiák exponenciálisan fejlődnek, az oktatás területén működő robotok segítségével ma még szinte hihetetlen dolgokat fogunk tudni megtenni. Érdekes, hogy néhány kínai iskola már olyan arcfelismerési technológiát használ, amely 30 másodpercenként megvizsgálja a hallgatók arcát, és visszajelzéseket ad a tanároknak (England, 2018; Chan, 2018), hogyan lehetne javítani vagy jobban személyre szabni tanítási módszereiket. A gyógypedagógiai gyakorlatban ez hatalmas távlatokat nyithatna a fejlesztés, terápiák területén. A nemzetközi szakirodalom szerint a jövőben valószínűsíthető, hogy a robotok jelenléte állandósul az iskolákban, mely lehetővé teszi majd a pedagógusok számára, hogy jobban megismerjék a diákokat, lehetővé téve számukra a személyes motivációt és a személyre szabott tanulást.

A következő hét-tíz évben a virtuális valóság lehetőségeit szintén széles körben fogják használni az oktatási folyamatban, mivel olcsók és majdnem kézzelfogható tapasztalatokkal bírnak, melyek segítenek a diákoknak a gyors és hatékony elsajátításban (Mozaik, 2016).

Mivel a technológia szinte bármit lehetővé tesz majd a következő tíz-tizenöt évben, fontos, hogy továbbra is megpróbáljuk elemezni a használatá- 
nak hosszú távú hatásait. Minden új technológiát felelősségteljesen kell felhasználnunk, mindig az etikai irányelveket és szabványokat követve. Végül, ne felejtsük el, hogy a robotokat az emberek kiszolgálására fejlesztették ki, nem pedig fordítva.

\section{Irodalom}

Aknai, D.O., \& Fehér, P. (2019).Kalandozásokrobotméhecskével-Problémamegoldás, gondolkodásfejlesztés padlórobotokkal. Debreceni Egyetemi Kiadó, IKT MasterMinds Kutatócsoport.

Aknai, D. O., \& Birinyiné Kleszó, A. (2019). SNI diákok képességfejlesztése okos eszközökkel és robotokkal. Konferencia-előadás. III. Jelen és jövő: számitógépek és okos eszközök az iskolában konferencia és workshop. 2019.04.05.

Balogh, L. (1987). Képességfejlesztés és iskolai tanulás: problémák és megoldások. https://mek.oszk.hu/04600/04669/html/balogh_pedpszich0022/balogh_ pedpszich0022.html (2020.04.16)

Benitti, F. B. V. (2012). Exploring the educational potential of robotics in schools: a systematic review. Computational Education, 58(3), 978-988. https://doi. org/10.1016/j.compedu.2011.10.006

Chan, T. F. (2018). A school in China is monitoring students with facial-recognition technology that scans the classroom every 30 seconds. Business Insider, https:// www.businessinsider.com/china-school-facial-recognition-technology-2018-5

Csapó, B. (1998, Ed.). Az iskolai tudás. Osiris.

Csapó, B. (2002, Ed.). Az iskolai müveltség. Osiris.

England, R. (2018). Chinese School Uses Facial Recognition to Make Kids Pay Attention, Engadget, https://www.engadget.com/2018/05/17/chinese-school-facialrecognition-kidsattention/ (2020.04.30.)

Feher, P., \& Aknai, D. O. (2018). Computational thinking in problem solving: A theoretical overwiev. In Vidákovich, T., \& Füz, N.(Eds.), Programme and Abstracts. 16th Conference on Educational Assessment, (p. 30.). University of Szeged. http://www.edu.u-szeged.hu/pek2018/download/2018_PROGRAMME_ ABSTRACTS.pdf (2020.04.24.)

Feher, P., \& Aknai, D. O. (2019). Wandering Robots in Hungarian Primary Schools: a Case Study. European Conference on Educational Research. https://eera-ecer. de/ecer-programmes/conference/24/contribution/49025/ (2020.04.24.)

Fehér, P., \& Aknai, D. O. (2020). Robotok alkalmazásának legújabb eredményei az általános iskolában - nemzetközi kitekintés. (elfogadott előadás) Pedagógiai Értékelési Konferencia.

Feher, P., \& Aknai, D. O. (2020, Aug 25-28.). Robotics for Special Education Needs Students - First Results of One-year Qualitative Research. (accepted paper) European Conference on Educational Research. 2020. Aug. 25-28. 
Feil-Seifer D., \& Mataric, M. J. (2005). Defining socially assistive robotics, Rehabilitation robotics, ICORR 2005. In 9th International Conference, (p. 465-468). https:// robotics.usc.edu/publications/media/uploads/pubs/442.pdf (2020.04.18.)

Fong, T., Nourbakhsh, I., \& Dautenhahn, K. (2003). A survey of socially interactive robots. Robotics and Autonomous Systems. 42, 143-166. https://www.cs.cmu. edu/ illah/PAPERS/socialroboticssurvey.pdf (2020.04.18.)

Gácsi, M. (2013). Robotok lesznek a társaink? A kutya, mint modell, Mindennapi Pszichológia, 5(1), 54-57. http://etologia.elte.hu/file/tudomanyos/Mipszi\%20 Robot\%20GM.pdf (2020.04.30.)

Gósy, M. (2009). A beszédészlelés és a beszédmegértés fejlesztése (szóban és irásban) iskolásoknak. Nikol Kkt.

Houwen, S., van der Putten, A., \& Vlaskamp, C. (2014). A systematic review of the effects of motor interventions to improve motor, cognitive, and/or social functioning in people with severe or profound intellectual disabilities. Research in Developmental Disabilities, 35(9), 2093-2116.

https://journals.sagepub.com/doi/10.1177/1362361319885215

Hwang, J., \& Taylor, J. C. (2016). A STEM Education Framework for Students with Disabilities. Journal of Science Education for Students with Disabilities 19(1), 39-49. https://doi.org/10.14448/jsesd.09.0003

Miller, D. P. (1998). Assistive robotics: an overview. In Mittal, V. O., Yanco H. A., Aronis, J., \& Simpson, R. (Eds.), Assistive technology and artificial intelligence. (pp. 126-136). Springer. https://link.springer.com/chapter/10.1007/BFb0055975 (2020. 04.16.)

Molnár, Gy. (2012). A problémamegoldó gondolkodás fejlődése: Az intelligencia és a szocioökonómiai háttér befolyásoló hatása 3-11. évfolyamon. Magyar Pedagógia, 112(1), 41-58. http://www.magyarpedagogia.hu/document/Molnar_ MP1121.pdf (2020.04.24.)

Molnár, Gy. (2016). A dinamikus problémamegoldó képesség mint a tudás elsajátításának és alkalmazásának képessége. Iskolakultúra, 26(5), 3-16. http:// epa.niif.hu/00000/00011/00205/pdf/EPA00011_iskolakultura_2016_05_01.pdf (2020.04.24.)

Mozaik Education (2016). Mozaik Virtual Reality 3D. Mozaik Kiadó. Imosoft Kft. https://www.mozaweb.hu/course.php?cmd=single_book\&bid=MS-9853-VRHU (2020.04.26.)

Nagy, J. (2003). Az eredményesebb képességfejlesztés feltételeiről és lehetőségeiről. Iskolakultúra, 13(8), 40-52. http://www.edu.u-szeged.hu/difer/download/nagy_ kepessegfejlesztes.pdf (2020.04.16.)

Nagy, J. (2002, Ed.). Az alapkészségek fejlódése 4-8 éves életkorban. OKÉV, KÁOKSZI. http://www.edu.u-szeged.hu/difer/download/jozsa_szamolasi.pdf (2020.04.16.)

OECD (2010). PISA 2012 problem solving framework (draft for filed trial). OECD. https://www.oecd.org/pisa/pisaproducts/46962005.pdf (2020.04.22.) 
Palestra, G., \& Bortone, I. (2016). Perspective Ethical Issues about Experiences with Social Robots to help Children with Autism Spectrum Disorders. In New Friends Conference Proceedings Ethical, Legal and Societal Issues of Robots in Therapy and Education Workshop. https://doi.org/10.3926/newfriends2016

Palestra, G., Esposito, F. ,\& De Carolis, B. (2017). A Multimodal Interface for RobotChildren Interaction in Autism Treatment, 158-162. http://ceur-ws.org/Vol1982/paper3.pdf (2020.04.24.)

Pólya, Gy. (1969). A gondolkodás iskolája. Gondolat Kiadó.

Ribu, K. (2010). Teaching Computer Science to Students with Asperger's Syndrome. In Proceedings from NIK The Norwegian Informatics Conference. https://www. scribd.com/document/177838483/Teaching-Computer-Science-to-Studentswith-Asperger-s-Syndrome (2020.04.24.)

Scassellati, B. (2005). How Social Robots Will Help Us to Diagnose, Treat, and Understand Autism. The International Journal of Robotics Research, 28, 552-563. https://www.researchgate.net/publication/220757236_How_Social_Robots_ Will_Help_Us_to_Diagnose_Treat_and_Understand_Autism (2020.04.24.)

Scassellati, B., Admoni, H., \& Matarić, M. (2012). Robots for use in autism research. The Annual Review of Biomedical Engineering, 14, 275-294. https:// www.annualreviews.org/doi/pdf/10.1146/annurev-bioeng-071811-150036 (2020.04.18.)

Villanueva, M. G., Taylor, J., Therrien, W., \& Hand, B. (2012). Science education for students with special needs. Studies in Science Education, 48(2), 187-215., https://doi.org/10.1080/14703297.2012.737117 


\section{Aknai Dóra, O.}

\section{The role of robotics in the development of SEN students}

Educational robotics is one of the most relevant topics of ICT research. It is also used in activities with a variety of students with special educational needs. In this paper our goal was to highlight the relation of problem-solving, competency development and using ICT-tools (eg. different types of floor-robots). We give an overview based on literature about the implementation of floor robots into classroom lessons and as well as about the challenges of their usage. In the study we also present several methodological and robotics tools that can be used in working with children with SEN. The detailed information about floor-robots help teachers to choose an adequate tool for their aims.

Keywords: robotics, SEN, competency development, problem-solving thinking, floor-robots

Aknai Dóra Orsolya: https://orcid.org/0000-0003-3463-3538 